\title{
The Challenge of Curriculum Integration for Islamic Universities: Setting the Principles of Curriculum Integration
}

\section{Saheed Ahmad Rufai ${ }^{1}$}

\begin{abstract}
The Muslim world witnessed remarkable developments in its educational system in the last four decades. Such developments include the founding of schools, establishment of universities, publication of journals, and organization of conferences and production of books, for the purpose of Islamization. It is obvious that knowledge is central to all these Islamizing initiatives as its integration is fundamental to the entire process of Islamization. Consequently, there are contributors to the curriculum integration level of Islamization by Muslim scholars across the world who have attempted to Islamize knowledge in their various areas. However, there is little attention to the professional requirements for integration of knowledge for Islamization especially at the university level. That informed the question, whose job is it to integrate the curriculum for Islamic universities? The purpose of this paper is to address this question. Utilizing a combination of the analytical method and creative synthesis, this paper is grounded in the scholarship of pragmatist philosophical foundations of the curriculum. It is hoped to provide guiding principles to the practice of integrating knowledge for Islamization. Such principles for curriculum development for Islamic universities, may also curb the growing trend of curriculum integration without the
\end{abstract}

\footnotetext{
${ }^{1} \mathrm{PhD}$, Department of Curriculum Studies, Faculty of Education, Sokoto State University. Nigeria, Email: ahmadrufaisaheednew@yahoo.com
} 
requisite professional curriculum-making considerations, portraying the Islamization of Knowledge (IOK) project as unsystematic.

KEYWORDS: Curriculum Integration; Knowledge Integration; Islamization of Knowledge; Islamic Universities; Curriculum and Pedagogy

\section{Introduction}

Contemporary Islamic universities and academic institutes are generally regarded as the engine room propelling advances in the Islamization of Knowledge (IOK) project. This conjuncture finds some evidence in the institutional spread of the pioneers and leading promoters of the project who are strongly associated with some of the most reputable institutions. It therefore may not be inconceivable to rationalize that the Islamic universities and academic institutes were founded for the purpose of advancing or perfecting the process of Islamization. Naqi (1987:47) captures this line of thinking where he alludes to the founding of the International Institute of Islamic Thought (IIIT) in the United States of America in 1981, the establishment of the Work Centre for Islamic Education in Saudi Arabia also in 1981, and the inauguration of the Islamic Academy in the United Kingdom in 1983.

Ssekamanya and Rosnani (2012) similarly identify the subsequent emergence of Islamic universities in Malaysia, Islamabad, Uganda, Niger, Dhaka and Indonesia as a reflection of significant progress in the IOK project. One of the common demonstrators in the academic and administrative operations of these universities is the perceived commitment to the "liberation of man first from magical, mythological, animistic, nationalcultural tradition, and then from secular control over his reason and his language”. (Al-Atlas, 1990: 45-46). For instance, the International Islamic University Malaysia which, according to Ssekamanya and Rosnani (2012:5), "is the premier Islamic university globally at the moment, accords IOK a core status in its vision and mission, and makes it the primary feature in all programme learning outcomes, course contents and evaluation methods".

According to Amin, Yusof and Haneef, (2013) the idea of founding Islamic universities was a product of 
recommendations made at the First World Conference on Muslim Education held in Makkah in 1977. The conference felt the need for the improvement of "the quality of teaching, learning and research of Islamic heritage by Islamic universities with an integrated curriculum” (p.1). Consequently, IIUM emerged in 1983 as a response to the quest for the implementation of the integrated curriculum model advocated at the conference. Ssekamaya, Suhaila and Nik Ahmad (2011) opine that the university has been committed to the integration of Islamic values with the modern fields of knowledge right from its inception. Several graduates, scholars and researchers associated with this or other Islamic universities have been very active in the pursuit of the objectives of IOK in their various areas of operations, including the publication of textbooks. Adebayo (2012:95) has identified the proliferation of such publications as a reflection of "the level of acceptability of the Islamization of Knowledge programme.”

He further claims that the IIIT "has published thousands of textbooks in English, Arabic and other world languages” (p. 95). Queries concerning the validity or otherwise of his claim that "thousands of textbooks have been published" by the IIT in various languages, for the purpose of Islamization are rendered insignificant by the temptation to examine the quality of such publications with regard to the curriculum integration dimension of the project. How could there have been "thousands of textbooks" when some of the leading participants in the Islamization project, even recently identified the dearth of textbooks with the Islamic perspective or worldview in various disciplines, as one of the major barriers against the project (Sskamanya \& Rosnani, 2012).

Noraini and Langulung (2008) identify Malaysia as one of the earliest countries to imbibe the curriculum change along the path of integration, as advocated in connection with the IOK 
project. Noraini and Langulung (2008:13) further argue that the New Primary School Curriculum (NPSC) was changed in 1983 to Integrated Curriculum for Primary School (ICPS) whereas the New Secondary School Integrated Curriculum for Secondary Schools (KBSM) was introduced for lower secondary level in 1988 and later implemented at all secondary levels in 1989. The relevance of these developments to the present discourse lies in the fact that the curriculum in question was fashioned out in consonance with the recommendations of the First World Conference on Muslim Education Rosnani (2004) gives a good account of this historic educational development and its aftermath in her magnum opus, Educational Dualism in Malaysia. Despite the appreciable improvement in curriculum and institutional practices at the elementary level of education, Rosnani (2004) enumerates a multiplicity of challenges in the Malaysian attempt to bring about the integrated curriculum system.

However, such a question may not be addressed in detail in the present paper whose focus is curriculum integration in curriculum development for Islamic universities. Amin, Yusof and Haneef (2013:2) emphasise the need for the conduct of a careful structuring of the curriculum to ensure that knowledge, skills and spiritual development, and thus market needs, are realized" in any effort calculated at integrating higher education curriculum in consonance with the Islamic principles. The concern expressed here shows that failure to demonstrate this professional requirement in some of the efforts made so far at integrating curriculum for higher Islamic education may have created the impression that IOK can only be revived by "recognizing the primacy of expanding knowledge over the necessity of ensuring the use of knowledge" (Siddiqi,, 2009:1533). Such a concern, among other factors, has informed the need to re-examine the curriculum integration level especially in connection with curriculum development for Islamic 
universities, with a view to addressing the question, whose job is it to integrate curriculum?

\section{Problem Statement}

There has been a proliferation of publications especially textbooks for the purpose of Islamization. Such textbooks have gradually earned acceptance and recognition as Islamic curriculum materials for schools and colleges. While some efforts may always be welcome and appreciated at lower levels of education owing to its generalist nature, the nature of expertise and advancement that characterize scholarship at the university level may not always overlook such a generalist response to specialized questions. Hence the question, whose job is it to develop an integrated curriculum for Islamic universities?

\section{Statement of Purpose}

This paper is intended to address the central question, whose job is it to perform curriculum integration for Islamic universities? In specific terms, the paper seeks to:

(i) Examine the concept of integrated curriculum and its implications;

(ii) Articulate professional requirements for curriculum integration for contemporary Islamic universities.

(iii) Formulate a framework for the preparation of professional manpower for curriculum integration in Islamic universities.

\section{Research Questions}

This study is guided by the following three questions:

1. What is the implication of curriculum integration?

2. What are the professional requirements for curriculum integration for contemporary Islamic universities? 
3. What framework has potential for the preparation of manpower for curriculum integration for Islamic universities?

\section{Methodology}

This paper, which is essentially of qualitative orientation, employs a combination of three methods, namely analytic philosophy, curriculum criticism, and creative synthesis. It is, however, intended to later incorporate some quantitative data for the purpose of measuring what proportion of the existing contributors to curriculum integration for Islamic universities, has the requisite professional background. The aim of such an extended study shall involve determining the effect of such deficiency on the quality of the progress recorded so far in curriculum integration for Islamization. In specific terms, a critical analysis of salient issues in the study is carried out through the use of the analytical method, which is also used in analyzing data from literature and in providing the implication of specific principles. Essentially, the techniques of criticism or the philosophical method are of central importance to any critical work.

The study also employs curriculum criticism and creative synthesis in setting curriculum principles. The relevance of curriculum criticism in this connection lies in the fact that it provides a more comprehensive view of curricular and educational needs (Kliebard, 1992). "Curriculum criticism is premised on an analogy between the curriculum (as a set of materials offering experience to its recipients) and the work of art in any medium. The curriculum critic attempts to portray the experience offered by the work and especially the experiences offered to students. The critic serves as a bridge between a curriculum and school officials who must make a decision about it. This inquiry tool goes a step beyond the participant-observer 
methodologies of ethnography” (Ross, 2000: 176). In this study, it is employed in carrying out a comparative evaluation of the proposed model and the dominant Western models. The potency of this method in identifying the strengths and deficiencies in any educational blue-print, for possible improvement or endorsement features prominently in this paper.

As regards creative synthesis, its relevance to this study stems from its nature as a tool for the combining of separate elements to form a coherent whole (Ross, 2000). The formulation of curriculum integration principles from the Islamic worldview and other sources is not without its creative and synthetic dimension. Hence the use of creative synthesis in this study especially with regard to the core principles and criteria of the integration curriculum that are derived from the primary sources of curriculum construction. It may be added that creative synthesis as a method for this paper comes to the fore in the derivation of the core principles for the formulation of a curriculum framework for manpower training for curriculum integration. This method, it should be noted, is primarily associated with the systematic selection and organization of different components into an interlinked unit or interlocked whole. This is particularly the situation where this paper formulates or generates both conceptual and structural curriculum principles from the scholarship of curriculum construction as well as from some of the best practices in teacher education in the context of today.

\section{Significance of the Study}

This study offers the potential of an eye opener over the need for expertise in various segments of the IOK project. Such revelation, as will be made, may inform either the consolidation of or gradual withdrawal from the current practice of 
indiscriminate acceptance of integrated educational blue-prints as standard. The study ultimately seeks to stimulate a rethink on IOK-related policies with regard to integrated curriculum designing.

\section{Theoretical Framework}

The study is grounded in the scholarship of the philosophical foundations of the curriculum. It draws on pragmatism in exposing the deficiencies in the current practice of curriculum integration for Islamic universities which rather than being existentialist by according learners some liberty to negotiate the direction of curriculum, is largely idealistic and partially perennialistic, especially with regard to the role of the teacher in both curriculum and instruction. It is not out of place to add that pragmatism, which is a philosophy of education derived from the teaching of Charles Sanders Peirce (1839-1914) is grounded in the thinking that thought must culminate in activity rather than linger in the mind and yield passivity. In the educational parlance, John Dewey (1859-1952) applied the principles of pragmatism to demonstrate that learners must adapt to each other and to their environment in a manner that will make learning a problem-solving endeavour.

The relevance of such a philosophy to the present study lies in its emphasis on the process of result-oriented learning which is the purpose of curriculum integration. Existentialism shares the principles of pragmatism in the context of curriculum integration in view of the dominant existentialist orientation that educational experience is better focused on the creation of opportunities for self-direction and self actualization among students and better targeted at the student rather than at the curriculum content. It is the argument of this paper that neither the dominant idealistic outlook which seeks to develop the individual's abilities and full moral potentials for the purpose of developing the society nor the substantially perennialist 
orientation whose focus lies in experiences that are of everlasting pertinence to all people everywhere, or ideas that have lasted over centuries, is adequate and appropriate for a system committed to the idea of curriculum integration.

\section{The Concept of Curriculum Integration}

This section is an attempt to answer the Research Question 1 namely, What is the implication of curriculum integration? The concept of curriculum integration is concerned with the professional deployment of creativity by the curricularist in a bid to fashion out a new educational blue-print from a set of learning materials. It is an innovative method of organizing learning for a systematic delivery. Loepp (2007) however argues that it is not a new method of organizing instruction and maintains that "educators first explored the concept of integrating curriculum in the 1890s", citing such notable curricularists and educational researchers as Drake (1998), Cook (1992), Drake and Burns (2004), Beane (1996 \& 1997), Bishop and Brinegar (2011), Jacobs (1989), Pring (1973), Jensen (1998), and Mansfield (1989) who have variously described the concept of integrated curriculum as interwoven curriculum, connected curriculum, thematic curriculum, interdisciplinary curriculum, multidisciplinary curriculum, correlated curriculum, linked curriculum, and holistic curriculum.

The present writer conceives of such various interpretations as conveying the idea of creative curriculum and innovative educational blue-print, as earlier articulated in his definition of the concept. However, Lake (2011) favours the perception of integrated curriculum as "interdisciplinary" and "thematic" and further describes it as "synergistic" but emphasizes the need to cast a careful look at the related terms that are associated with the concept, in order to have a clear picture of what it is and what it is not. The present writer believes such a note of warning as offered by Lake (2011) in this 
connection, signals the possibility of misconceptions and misapplication of the idea of curriculum integration.

In the opinion of Lake (2011), integrated curriculum is identified as an academic experience “... in which children broadly explore knowledge in various subjects related to certain aspects of their environment” (p, 9). He argues that the idea of curriculum integration is an attempt to connect various areas of learning such as 'the humanities, communication arts, natural sciences, mathematics, social studies, music and art" for the purpose of bringing about a unified learning blue-print. Dressel (1958: 3-25) had earlier argued that an integrative approach to curriculum not only equips the learners with "a unified view of commonly held knowledge...but also motivates and develops learners' power to perceive new relationships and thus creates new models, systems and structures.

As useful and interesting as some of the perspectives offered in the foregoing may be, it may be argued that such lines of thinking about, conceiving of, and understanding integrated curriculum account for the growing confusion that characterizes the scholarship of curriculum integration so much that the diverse and conflicting nature of educational scholars' and researchers' views on the highly technical but seemingly simplistic concept now makes challenging the demarcation between what it is and what it is not. It may be further argued that the misconception occasioned by the preponderance of misleading scholarship on the subject or concept, tends to promote the perception that curriculum integration is not an exclusive preserve of a particular section of scholarship and is therefore open to contributions from lay persons or any scholar with some idea of knowledge combination!

The concept, it should be noted, has received a good attention in the works of contemporary curricularists (Beane, 
1997; Drake, 1998; Fraser \& Charteris, 1998; Fraser, 2000; Fraser \& Paraha, 2002; Etim; 2005; and Pring, 2006). However, only little effort has been made to expose the confusing elements that are somewhat instrumental to the misconception of curriculum integration as "thematic" and all that were stated earlier, in that regard. It is of great value to state at this juncture that curriculum integration, unlike the thematic units, "does not focus on a particular topic chosen by the teacher; does not attempt to cover the curriculum; does not necessarily involve the teacher in both planning and directing students in activities which may enable a teacher "to plan in advance and recycle units from year to year” (Fraser, 2000”39) Table 1 captures the essence of the concept of curriculum integration as against the dominant related misconceptions.

Table 1: A tabular analysis of misconceptions about curriculum integration

\begin{tabular}{|c|c|c|}
\hline $\mathbf{S} / \mathbf{N}$ & $\begin{array}{l}\text { What curriculum integration } \\
\text { is }\end{array}$ & $\begin{array}{l}\text { What curriculum } \\
\text { integration is not }\end{array}$ \\
\hline 1 & $\begin{array}{l}\text { focuses on students' prior } \\
\text { lowledge and uses it as the } \\
\text { irriculum entry point. }\end{array}$ & $\begin{array}{l}\text { It is not all about rearranging } \\
\text { lesson plans to fill gaps in } \\
\text { subject areas. }\end{array}$ \\
\hline 2 & $\begin{array}{l}\text { It views subjects as } \\
\text { interconnected rather than } \\
\text { isolated from one another. }\end{array}$ & $\begin{array}{l}\text { It is not the teaching of } \\
\text { thematic units whereby a } \\
\text { central topic forms the } \\
\text { "theme" while each subject is } \\
\text { examined for its relevance to } \\
\text { the theme. }\end{array}$ \\
\hline 3 & $\begin{array}{l}\text { tudents' } \\
\text { ting the } \\
\text { acher. }\end{array}$ & $\begin{array}{l}\text { It is not simply aimed at } \\
\text { providing students with } \\
\text { information about the topic. }\end{array}$ \\
\hline 4 & $\begin{array}{l}\text { It is issues-oriented rather that } \\
\text { topic-driven. }\end{array}$ & $\begin{array}{l}\text { It does not search for topics in } \\
\text { various learning areas for } \\
\text { possible contribution to the } \\
\text { theme. }\end{array}$ \\
\hline 5 & $\begin{array}{l}\text { It involves pedagogical } \\
\text { creativity on the part of the } \\
\text { teacher to determine what is }\end{array}$ & $\begin{array}{l}\text { It is not stereotypical and } \\
\text { committed to covering the } \\
\text { curriculum. }\end{array}$ \\
\hline
\end{tabular}


best for every stage of his teaching.

6 Appropriate learning areas naturally

Emerge during teacher's opening interaction with his students and therefore do not enable him fully plan in advance.

7 It underscores distinctions between subjects or learning areas for balance or organization.

8 It seeks to preserve the integrity of each subject.

9 Required learning areas are drawn upon from issues that form the centre

It does not claim all learning areas are common or the same.

It is not favourably disposed to the recycling of learning units.

It does not distort information to confer undue advantage or preference on any specific area of learning.

Curriculum design derives from subjects which are placed at the centre

10 Teacher is less involved as director but more as negotiator with students.

It is essentially teacheroriented.

Source: The author's analysis in Table 1 is indebted to Fraser (2000).

It is obvious from the foregoing that curriculum integration is not what it is perceived to be by most of the scholars who offer the perspective that, it is simply thematic. It may be argued that the misconception of the idea of curriculum integration which is one of the cardinal foci of Islamic universities as articulated in the mission statement of IIUM namely Integration, Islamization, , Internationalization and Comprehensive Excellence, is not without some bearing on the level of achievement or degree of progress recorded so far in the IOK project. The present writer argues that lack of good grasp of the concept of curriculum integration or its unintended misapplication for the purpose of curriculum development for Islamic universities may constitute a hindrance to the full realization of the laudable objectives of the 
project. Figure 1 offers a clear picture of the three major dimensions of curriculum integration, as a continuum.

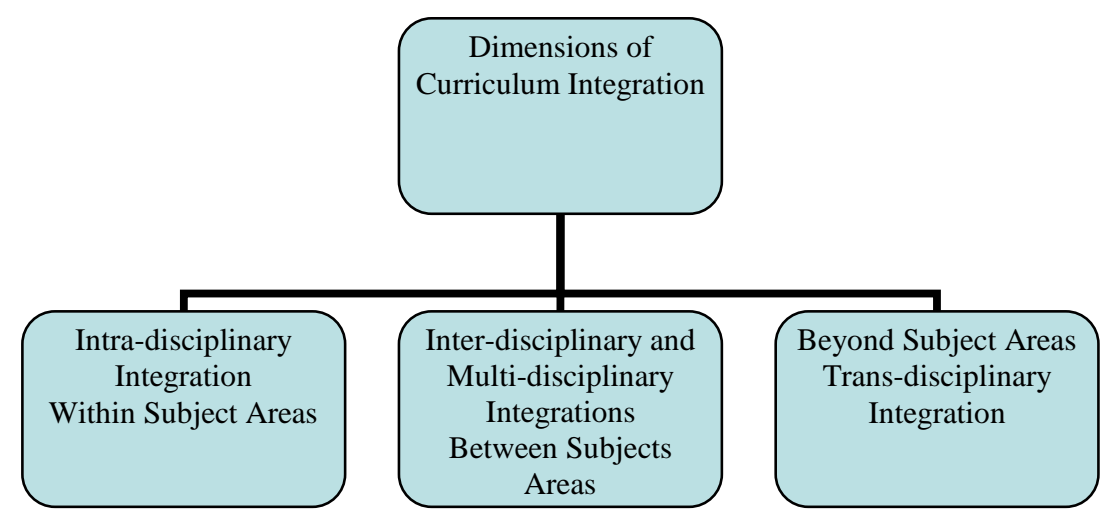

Figure 1: The three main dimensions of curriculum integration as adapted from Loepp (2007).

Contemporary curricularists maintain that unless it is well conceived of, clearly thought out, meaningfully articulated and correctly implemented, "curriculum integration can become as forced or artificial as any poorly executed approach, resulting in lack of student motivation and engagement” (Beane, 2005; Jacobs, 1993; Murdoch \& Hamston, 1999, cited in Fraser, 2011:27). This argument finds support in the opinion of one of the two main originators of the idea of Islamization, Prof. Ismail Al-Faruqi, who identifies lack of clarity of educational directions as one of the handicaps limiting the progress of Muslims in various walks of life. (Al-Faruqi, 1982). This issue has remained one of great concern for sometime now.

It is obvious that notable advocates of Islamization in various parts of the globe have contributed significantly to what may facilitate or navigate way for appreciable scholarship in the 
area of curriculum construction for Islamic universities or higher Islamic education (Al-Attas, 1978, 1979; Al-Faruqi, 1982; Abu Sulayman;1989, 1993; Amin \& Haneef, 2011) In recent times Rosnani (1996, 1997, 2004, 2007, 2012, 2014) has been in the vanguard of curriculum construction for higher Islamic institutes. However, the need to distinguish the dominant thematic approach to curriculum making in the IOK parlance, from the desired and much sought integrative approach for Islamization,, seems not to have received its deserved attention. The problem arising from this omission in the contemporary scholarship of Islamization is not unconnected with the concern expressed by Virture, Wilson and Ingram (2009 cited in Fraser, 2011) who posit that "teachers transiting from a thematic curriculum to a fully integrated approach are likely to face some difficulties owing largely to the centrality of experience in cross-curriculum planning and negotiating with students, to the success of the integrated approach. Ssekamanya and Rosnani (2012) affirm that there are many lecturers in Islamic universities, IIUM inclusive who are not clear about the Islamization agenda. Figure 2 shows the interlinked nature of various levels of curriculum integration and exposes sources of other curriculum variants of conceptions and approaches to integrative curriculum-making, which may confuse lay contributors to curriculum integration. 


\begin{tabular}{|c|}
\hline Language Arts \\
\hline Social Studies \\
\hline Mathematics \\
\hline Foreign Languages \\
\hline Physical Education \\
\hline Art \\
\hline Home Economics \\
\hline Technology Education \\
\hline Music \\
\hline
\end{tabular}

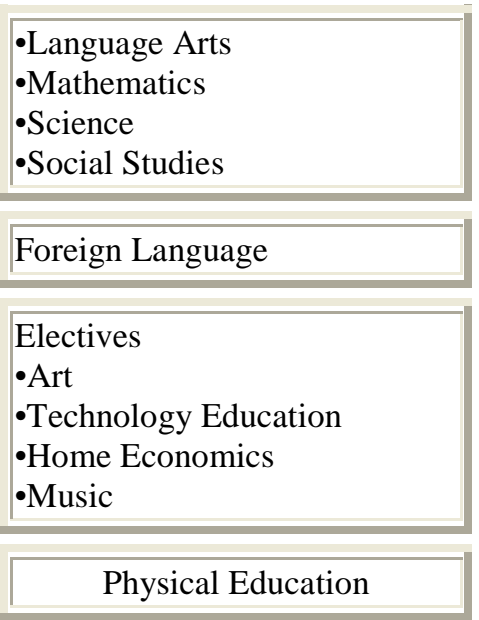

Figure 2: A generic illustration of the inter-disciplinary model of curriculum integration.

Source: Fraser (2011)

There is no strain in stating that any of these levels may be easily mistaken for another integrative level. One may now appreciate the need to lay out the requisite professional background that has the potential of equipping a scholar for performance in curriculum integration which constitutes the curriculum focus of Islamic universities in their Islamizing initiatives and operations. For the wheel to come full circle, the various dimensions of curriculum integration that are practiced, at varied degrees of accuracy and inaccuracy, among claimants to integrated curriculum in contemporary Islamic university settings, are graphically captured by Forgarty (1991), as shown in the following Table 2 .

Table 2: A summary of ten levels of curriculum integration as addressed by Forgarty (1991). 


\begin{tabular}{|c|c|c|c|}
\hline Name & Description & Advantages & Disadvantages \\
\hline Fragmented & $\begin{array}{l}\text { Separate and distinct } \\
\text { disciplines }\end{array}$ & $\begin{array}{l}\text { Clear and discrete view of } \\
\text { a discipline }\end{array}$ & $\begin{array}{l}\text { Cormections are not made } \\
\text { clear for studerts; less } \\
\text { transfer of learning }\end{array}$ \\
\hline Cormected & $\begin{array}{l}\text { Topis within a discipline } \\
\text { ane cormected }\end{array}$ & $\begin{array}{l}\text { Key conoepts are } \\
\text { comected, leading to the } \\
\text { review, reconcept- } \\
\text { ualization and assirrilation } \\
\text { of ideas within a discipline }\end{array}$ & $\begin{array}{l}\text { Disciplines are not related; } \\
\text { content fooss remains } \\
\text { within the discipline }\end{array}$ \\
\hline Nested & $\begin{array}{l}\text { Social, thinking, and } \\
\text { contents shlls are targeted } \\
\text { within a sub ject area }\end{array}$ & $\begin{array}{l}\text { Gives attertion to several } \\
\text { area at onoe, leading to } \\
\text { enviched and enhanced } \\
\text { learring }\end{array}$ & $\begin{array}{l}\text { Studerts maybe confused } \\
\text { and lose sight of the main } \\
\text { comopts of the activity or } \\
\text { lesson }\end{array}$ \\
\hline Sequenced & $\begin{array}{l}\text { Sirrilaridea are taught in } \\
\text { comoert, although sub jects } \\
\text { are separate }\end{array}$ & $\begin{array}{l}\text { Fxilitates trarsfer of } \\
\text { learring arross content } \\
\text { areas }\end{array}$ & $\begin{array}{l}\text { Requires ongoing } \\
\text { collaboration and } \\
\text { flexbility, as teachers } \\
\text { have less autonomy in } \\
\text { sequencing cumioula }\end{array}$ \\
\hline Shared & $\begin{array}{l}\text { Team plamring andior } \\
\text { teaching that involves two } \\
\text { disciplines focuses on } \\
\text { shared concepts, shills or } \\
\text { attitudes }\end{array}$ & $\begin{array}{l}\text { Shared instructional } \\
\text { experienoes; with two } \\
\text { teachers on a team it is } \\
\text { less difficult to collaborate }\end{array}$ & $\begin{array}{l}\text { Requires time, flexability, } \\
\text { comritment and } \\
\text { compromise }\end{array}$ \\
\hline Webbed & $\begin{array}{l}\text { Thematic teaching, using a } \\
\text { theme as a base for } \\
\text { instuction in many } \\
\text { disciplines }\end{array}$ & $\begin{array}{l}\text { Motivating for students, } \\
\text { helps studerts see } \\
\text { cormections between ideas }\end{array}$ & $\begin{array}{l}\text { Therme mustbe carefully } \\
\text { and thoughtfilly selected } \\
\text { to be mearingfill, with } \\
\text { relevant and rigorous } \\
\text { content }\end{array}$ \\
\hline Threaded & $\begin{array}{l}\text { Thinking s kills, social } \\
\text { skills, mulltiple } \\
\text { intelligenoes, and study } \\
\text { skills are "threaded" } \\
\text { troughout the dis ciplines }\end{array}$ & $\begin{array}{l}\text { Students leam how they } \\
\text { are leaming, facilitating } \\
\text { fiture transfer of leaming }\end{array}$ & $\begin{array}{l}\text { Disciplines remain } \\
\text { separate }\end{array}$ \\
\hline Integrated & $\begin{array}{l}\text { Prionities that overlap } \\
\text { multiple disciplines are } \\
\text { exarrined for oormon } \\
\text { skills, conoepts, and } \\
\text { attitudes. }\end{array}$ & $\begin{array}{l}\text { Enoourages students to see } \\
\text { intercormectedness and } \\
\text { inderrelations hips among } \\
\text { disciplines, studerts are } \\
\text { motivated as they see } \\
\text { these commections }\end{array}$ & $\begin{array}{l}\text { Requires interdepart- } \\
\text { mental teams with } \\
\text { common plarming and } \\
\text { teaching time }\end{array}$ \\
\hline Intuersed & $\begin{array}{l}\text { Leamer integrates by } \\
\text { viewing all learring } \\
\text { through the perspective of } \\
\text { one area of interest }\end{array}$ & $\begin{array}{l}\text { Integration takes plaoe } \\
\text { within the leamer }\end{array}$ & $\begin{array}{l}\text { May namow the foous of } \\
\text { the leamer }\end{array}$ \\
\hline Networked & $\begin{array}{l}\text { Leamer directs the } \\
\text { integration process } \\
\text { through selection of a } \\
\text { network of experts and } \\
\text { resources }\end{array}$ & $\begin{array}{l}\text { Pho-active, with leamer } \\
\text { stimulated by new } \\
\text { information, skills or } \\
\text { concepts }\end{array}$ & $\begin{array}{l}\text { Leamercan be spread too } \\
\text { thim, effort become } \\
\text { ineffective }\end{array}$ \\
\hline
\end{tabular}


One can see from Table 2 the distinctions among the concepts of connection, immersion, nesting, networking, webbling, threading, sharing, sequencing, fragmentation, and connection, in relation to curriculum integration. Forgarty (1991) deserves plaudits for presenting these related concepts in a meaningful tabular form.

Ssekamanya, Suhaila, and Nik Ahmad (2011) associate three approaches to curriculum integration at IIUM namely the comparative approach, the integrative approach and the "inculcative" approach. In the first approach, the same programme features different courses dealing with both the Islamic and the Western perspectives. In the second, both perspectives are taught side-by-side in the same course, with the assessment and evaluation in the course involving both perspectives. The third approach is described as "mainly used in technical and professional courses which have no philosophical presuppositions' in which case, 'focus is not on the course contents but on inculcating a positive Islamic character among students" (p. 98). However, it is obvious from the scholarship of curriculum integration that the three approaches, though largely synergistic, are no more than "thematic" in orientation. Evidence of this abound in the research on integrated curriculum, earlier reviewed in this paper. This lays credence to Rosnani'(2013)s allusion to Ssekamanya et al. (2007)'s finding that "many IIUM lecturers are still unclear about the Islamization agenda" . The present writer argues that a minor deviation from an original path has a tendency to lead to a wrong destination let alone a conceptual and structural error concerning the handling of knowledge which itself is the core of the IOK. Hence the need for the articulation of specific requirements for curriculum integration for Islamic universities, in keeping with Research Question 2 namely What are the professional requirements for curriculum integration for contemporary Islamic universities? 
and with a view to determining whose job it is to integrate curriculum for Islamic universities.

\section{Professional Requirements for Curriculum integration for Islamic Universities}

A grasp of both the revealed and the acquired knowledge has become generally known and accepted as a requisite for Islamization of knowledge. This view has been a recurring decimal in the works of leading contributors to the scholarship of Islamization of knowledge (AbuSulayman, 1989, 1993; AlAttas, 1978; Al-Alwani, 1989, 1995; Al-Faruqi, 1978; Amin \& Haneef, 2011; Rosnani, 1996, 1997, 2000, 2004, 2007, 2012, 2013). This has been interpreted as the need for a good command of the Islamic revealed (traditional) knowledge core, acquired (intellectual) knowledge core, acquired (intellectual) specialization and Islamic revealed (traditional) specialization (Rosnani, 2014). Figure 3 offers some idea of her line of argument in this regard. Ssekamanya and Rosnani opine that "a majority of IIUM staff are not proficient in the traditional Islamic sciences and the Arabic Language, both of which are crucial for effective IOK” (Ssekamanya \& Rosnani, 2012).

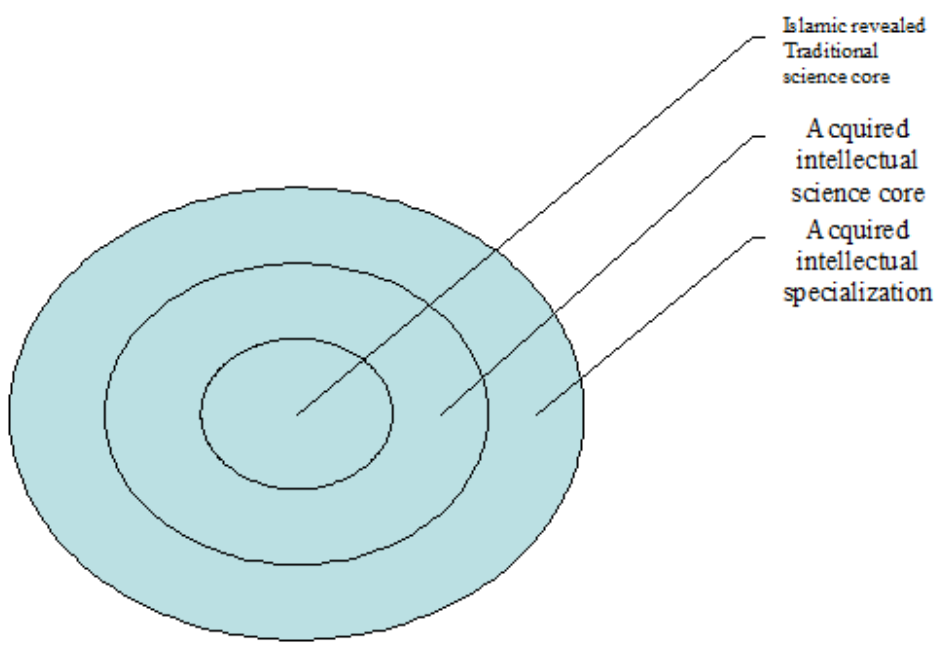

Figure 3: Rosnani’s proposed model

Source: Rosnani 2005; 2007; 2014. 
However, this view does not provide a lead concerning the specific measure of what is required from each of the various components articulated in the proposed model. Amin et al. (2013), as noted earlier, calls attention to the need for "a careful structuring of the curriculum" and this finds support in Rosnani (2014)'s opinion that curriculum designers for Islamic settings must know the theory and foundations of Islamic curriculum. She argues that the ever-evolving nature of the field of curriculum requires that "Muslim curriculum designers have to be creative and innovative and bring in key players from society, the industry and the experts” (p. 71).

It may be argued that a generalist knowledge of curriculum or any other area of learning for that matter, may not withstand the challenge of curriculum integration for Islamic universities. For instance, Fraser (2013) identifies the more dynamic, interactive and nuanced nature of curriculum integration than a thematic unit, as requiring a shift in the traditional role of the teacher. In specific terms, Fraser (2013:23) opines that curriculum integration "requires teachers to share decision making and the messy process of inquiry, where the outcomes are unknown” which makes it both demanding and daunting for those who are new to it. The implication of this is that curriculum integration requires rigour and may pose threat to scholars, teachers or curricularists with skewed scholarship. Figure 4 shows the interconnectedness of various areas of learning that a teacher may encounter in his integrative instruction. Such interconnectedness is evident in the interplay of mathematics, language arts, social studies, arts and sciences in one single classroom instruction, as shown below. 


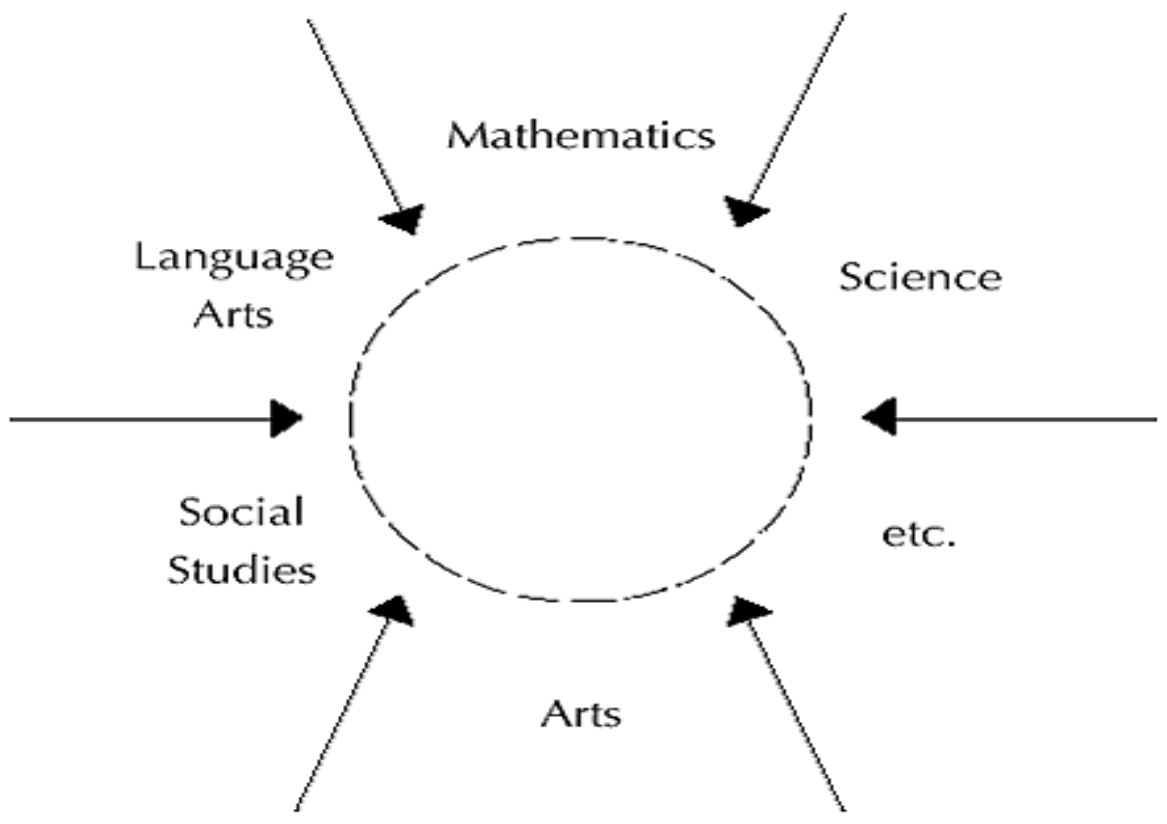

Figure 4: Loepp (2007)’s problem-based curriculum integration model

There have been reluctance and complaints of feelings of exhaustion by practitioners involved in the professional practice of curriculum integration especially those who can not withstand active engagement with students in the name of curriculum negotiation and therefore prefer to plan themselves well to make stereo-typical delivery. In other words, curriculum integration requires not only intellectual competence but certain professional dispositions including ability to withstand the rigour involved in the integrative process. Constructivist orientation is another requirement for curriculum integration. Here the curriculum maker may not expect the recipients of knowledge to accept, embrace, and memorize facts but apply 
their knowledge in problem-solving. Loepp (2007) identifies such requirements as extensive amount of professional development, integration into learning communities by collaborating with peers to improve education, skills for the facilitation of small group collaborative learning, for the management of experiential learning and for the conduct of integrative assessment strategies. Figure 5 shows desirable linkages among the various components of an integrated curriculum.

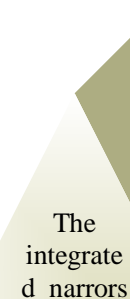

The academic load is redistributed in favour of the professional and specialized components, as the he or she progresses

An equal percentage of the core integrated courses in all the disciplines in the university including one's specialization. Every specialization has some components that enjoy the status of the university core or general education component

Figure 5: Rufai (2012)’s proposed interlinked model 
All these considerations are to be guided by the Islamic view of knowledge as represented by the Islamic tradition and contextualized into the contemporary Muslim settings for the purpose of addressing Modern educational and other challenges. The Islamic worldview or tradition and contemporary scholarship of curriculum-making, shall be the reference point in the formulation of principles for professional manpower development for curriculum integration in curriculum development for Islamic universities. The concluding part of this section alongside the next section shall constitute an attempt to answer Research Question 3, which is, What framework has potential for the preparation of manpower for curriculum integration for Islamic universities? I thought it appropriate to address such a question by starting with an analysis on the concept of principles in curriculum designing.

\section{The Concept of Principles in Curriculum Designing}

Principles are used among curricularists as the basis of evaluating programmes (Tom, 1997). Such a need normally arises when teacher educators seek an alternative to an existing set of standards which often prescribe course syllabi, arts and sciences in addition to education, or general procedures for programmes. Such standards are really regarded as rules (Paterson, 2003). As regards the present study, however, principles are seen as general statements that supply guidance but do not dictate precisely what must be done. Such principles as are derived in this study are aimed at determining what form of standard might provide some direction for teacher education in an Islamic setting. The principles seek to stimulate and encourage critical and creative programme development for an Islamic-based teacher education with a view to exposing the deficiency and inadequacy of the dominant models. The role of such design principles in a programme is highlighted by Alan (1997: 94) who writes, 
The role of design principles in programme creation has some similarities to the function of metaphors, yet important differences also exist. A metaphor, as a principle, can help expose long-held assumptions in teacher education, but a metaphor's utility for restructuring teacher education programming is limited. The best a metaphor can do is to provide a preliminary organization of intentions; that is, some implications. A principle can also provide a preliminary organization of intentions, but it should supply more specific guidance for programme reform than the implications contributed by a metaphor.

\section{Sources of Islamic Educational Principles}

It is worthy of mention that the issue addressed in this section has been addressed comprehensibly by the present researcher, elsewhere. For Muslim educationists to formulate a comprehensive, realistic, and effective educational principles, they must keep cognizance of a number of factors and refer to a number of sources (Al-Shaybani, 1979). Such factors and sources must be in consonance with Islamic doctrines, ethics, values, realities. They must also be capable of confirming the Islamic teachings on the purpose of creation, nature of man, human life on earth, the creator and his creatures and the Almighty God who is responsible for the being of all the above enumerated elements. Therefore, the Holy Qur'an, Sunnah of the holy prophet, qiyas (analogy) and ijma' (consensus) of Islamic jurists are all expected to rank first among the sources on which to ground educational theory or philosophy. Only such sources as identified above are capable of offering principles that are more realistic, effective and comprehensive than those offered by the man-made sources of principles.

It should be noted that the call for return to Islam is not merely a call to a lost heritage that must be regained but rather a call to a living, dynamic and ever-current source of guidance that is relevant to all places and ages. Besides, it is only through such a return that the Muslims can connect their present to their past by taking advantage of their traditional educational thought. 
Such a return also has the potentiality to facilitate a regain of educational and cultural identity and protect the intellects of their children from secularization and westernization of their values through alien and non-Islamic theories and philosophies. AsShaybani (1979: 31-32) identifies other sources of Islamic educational principles and describes such sources as only secondary or minor. They are:

1- Findings of authentic scientific studies concerning the nature of man and his character formation, growth, development, needs, interest, capabilities, intelligence, and other areas of interests in Psychology, Sociology, Biology, and Education that are of great value to a Muslim educationist in his formulation of philosophy. The Muslim educationist is enjoined to assess such findings with the Islamic standard, while making use of them

2- Findings of educational and psychological researches on human learning intellectual capabilities and psychological feelings. Closely related to the studies identified here are research to works on Sociology, Economics, and Culture

3- Personal experiences and experiments in the area of education as well as those of other successful nations and communities especially those sharing common culture and circumstances with us

4- Foundations of economic, political, and social philosophy being implemented in our society as well as declarations and stipulations of regional and international organisations to which belong Muslim nations, provided such stipulations or policies are in consonance with the Islamic teachings

5- Good values and traditions that are capable of aiding the realization the goals of an idea Muslim society, without impeding its development in line with the spirit of the time

It should be noted that the above enumerated sources are both interdependent and interrelated. It should be equally noted that the formulation of the principles below is guided by both 
curriculum designing principles and Al-Shaybani's perspective with regard to sources of principles.

\section{Guiding Principles for Professional Preparation for Curriculum integration for Islamic Universities}

Principle 1: A curricularist or curriculum integrator for an Islamic university must have a good mastery of the Islamic heritage which represents primary sources of knowledge. The implication of this is that there cannot be a meaningful integration of curriculum for an Islamic university without a good knowledge of the primary sources of knowledge in the Islamic tradition which essentially are the Qurán, the Hadith and others sources in the Islamic Heritage.

Principle 2: A curricularist or curriculum integrator for an Islamic university must possess a sophisticated Western scholarship that puts him in a good stead to relate conveniently with various areas of learning.

Principle 3: A curricularist/curriculum integrator for an Islamic university must be a versatile scholar with a good command of contemporary Islamic sciences including Arabic Language.

Principle 4: $\quad$ A curricularist/curriculum integrator for an Islamic university mush have advanced knowledge, skills, and experience of curriculum designing and development with high proficiency in curriculum integration.

Principle 5: A curricularist/curriculum integrator for an Islamic university must possess what it takes to derive guiding principles from various Islamic and Western sources either directly or through the aid of a secondary source in both perspectives. It is not only the knowledge involved that matters here but also the familiarity with both the Islamic and Western cultures in a manner that puts the curriccularist/knowledge integrator in a good stead to interpret and make appropriate 
inferences from various experiences, actions, attitudes, and dispositions.

Principle 6: $\quad$ A curricularist/curriculum integrator for an Islamic university must be creative and innovative and capable of shifting from a didactic to a constructivist role in interacting with learners who are not merely recipients of knowledge but partners in knowledge negotiation.

Principle 7: $\quad$ A curricularist/ curriculum integrator for an Islamic university must treat Islam as an inseparable part of human life. Accordingly, revelation, which is the source of religion, should be used as a guide for every aspect of knowledge or science. The emphasis here is on attitude

Principle 8: $\quad$ A curricularist/curriculum integrator for an Islamic university should be able to facilitate the end-result of a curriculum that will match the purpose of creation.

Principle 9: $\quad$ The integrated curriculum of the learners handled by a curricularist or curriculum integrator for an Islamic university should be committed to the realization of clear and realistic aims and objectives.

Principle 10: The integrated curriculum of an Islamic university should be balanced in philosophy and universal, holistic and all-encompassing in its curriculum content in order to be capable of replicating, at least to an appreciable extent, the wise man, sage or Hakeem, who was the central figure in the Islamic tradition.

Principle 11: The integrated curriculum for an Islamic university must be dynamic and keep cognizance of diversity in orientation, race, language, faith and others. It should be one that is open to innovation, adjustment, change and development in the light of societal, schools' or individual needs occasioned by modern challenges or articulated through systematic studies and investigations in the field of education and in consonance with Islamic religious principles. 
Principle 12: The integrated curriculum for an Islamic university should be convertible into tangible products for the human society at large and the Muslim community in particular, and should have adequate provisions in terms of sciences for the advancement of the comfort and welfare of the Muslim.

\section{An Analysis on the formulated principles}

The above principles are intended to guide performance in curriculum integration. Each of them contains a requirement for performance in curriculum making for Islamic universities. Principles formulated for the purpose of enhancing the quality of delivery among curricularists are meant to be translated for practical use. However, the space constraint of the present paper does not favour a venture into that. It will rather be subject of an extension of this study or a further research on the subject by the present writer or other scholars.

\section{Conclusion}

This paper has attempted to proffer an answer to the question, whose job is it to integrate curriculum for Islamic universities. The paper also attempted to address the concern arising from the indiscriminate attempts at Islamization of curriculum without any consideration or regard for the professional requirements for the highly technical endeavour. The paper argued that there is a missing link in the Islamization of Knowledge project which has knowledge at its core. It expressed some concern over the seeming deviation from or failure to capture the fundamental idea of curriculum integration by most of the participants in or contributors to the IOK project. The paper confirmed some of the findings of research assessing the progress of the project especially in the context of IIUM and with regard to the revelation that many of the scholars domiciled in Islamic universities, have not yet understood the Islamization agenda. The paper argued that a misconception of a central idea of an effort cannot favour or guarantee full realization of the objectives of such a project. Relying on the existing body of scholarship of curriculum designing, the paper examined the 
concept of curriculum integration and articulated specific professional requirements for curriculum integration for curriculum development for Islamization. Drawing on both the scholarship of curriculum and the growing research on Islamization alongside the researcher's professional experience in curriculum making, the paper offered a framework for possible preparation of professional manpower for curriculum integration for Islamic universities. The framework has, at least for now, taken the form of principles with potential to guide performance in curriculum integration for Islamic universities. Identifying whose job it is to integrate curriculum for Islamic universities, the paper recommended an extensive training in curriculum integration for select team of scholars in Islamic universities and also recommended the involvement of Muslim master curricularists in reviewing the curriculum integration outputs such as books and other learning materials, produced so far without requisite professional knowledge and skills for such highly technical tasks.

\section{References}

Abu Sulayman, A. H. (1989). Islamization of Knowledge. Riyadh: International Islamic Publishing House and IIIT.

Abu Sulayman, A. H. (1994). Islamization: Reforming Contemporary Knowledge. Herndon, VA: IIIT.

Abu Sulayman, A. H. (1989). Islamization of Knowledge: General Principles and Workplan. Herndon, VA: IIIT.

Adebayo, R.I (2012) A Survey on the Global Success of the Islamization of Knowledge Programme with Particular Reference to Nigeria, Journal of Al-Tamaddun, 6: 91-105.

Al-Alwani, T. J. (1995). Islamization of Knowledge: Yesterday and Today. AJISS, 12 (1): 81-101.

Al-Attas, S. M. N. (1978). Islam and Secularism. Kuala Lumpur: ABIM.

Al-Attas, S. M. N. (1980). The Concept of Education in Islam: A Framework of an Islamic Philosophy of Education. Kuala Lumpur: ABIM.

Al-Attas, S.M.N. (1990). The Concept of Education in Islam. Kuala Lumpur: ISTAC.

Al-Faruqi, I. R. (1982). Islamization of Knowledge. Washington DC: IIIT. 
Amin, R.M. \& Haneef, M. A. (2011). “The Quest for Better Economics Graduates: Reviving the Pliuralist Approach in the Case of the International Islamic University Malaysia.” International Journal of Pluralism and Economics Education 2 (1) 96-113.

Amin, E. M., Yusof, S.A. \& Haneef, M.A. (2013). The Effectiveness of an Integrated Curriculum. The Case of IIUM. Centre for Islamic Economics and Finance. Faculty of Islamic Studies, Qatar University.

Andrew, M.D. (1990). Differences between graduates of 4-year and 5year teacher preparation programs.Journal of Teacher Education, 41 (2),45-51.

Beane, J. A. (1997) Curriculum integration: Designing the core of democratic education. New York: Teachers College Press.

Beane, J. A. (2005). A reason to teach: Creating classrooms of dignity and hope.Portsmouth, NH: Heinemann.

Bilbe, R. (1992). "Primary Place: Teaching with Themes.” Instructor. 102 (2) 84-85.

Bishop, P.A. \& Brinegar, K. (2011). Student learning and engagement in the context of curriculum integration. Middle Grades Research Journal. 6 (4), 207-220.

Che Noraimi, H. \& Langgulung, H. (2008), Islamic Religions Curriculum in Muslim countries. The Experiences of Indonesia and Malaysia, Bulletin of Education and Research June 30:1(1-19).

Cook, j. (1992). Negotiating the curriculum: Programming for learning. In G. Booner, N. Lester, C. Onore, \& J. Cook (Eds), Negotiating the curriculum: Educating for the $21^{\text {st }}$ century (pp. 15-31). London: Falmer Press.

Dressel, P. "The Meaning and Significance of Integration." In The Integration of Educational Experiences, 57th Yearbook of the National Society for the Study of Education, edited by Nelson B. Henry. Chicago: University of Chicago Press, 1958, 3-25.

Drake, S. M. (1998). Creating integrated curriculum: Proven ways to increase student learning. Thousand Oaks, CA: Corwin Press.

Drake, S. M., \& Burns, R. C. (2004). Meeting standards through integrated curriculum. Alexandria, VA: Association for Supervision and Curriculum Development.

Etim, J. S. (2005). Curriculum integration K-12: Theory and practice. Lanham, MD: University Press of America.

Fraser, D. (2000). Curriculum integration: What it is and is not. set: Research Information for Teachers, 3, 34-37. 
Fraser, D., \& Charteris, C. (1998, October). What is curriculum integration and why do teachers need to know? Paper presented at the New Zealand Teacher conference, Hamilton.

Fraser, D., \& Paraha, H. (2002). Curriculum integration as treaty praxis. Waikato Journal of Education, 8, 57-70.

Fraser, D. (2011). Curriculum Integration, In (n.e. n.d.)Curriculum Integration, pp. 10-32.

Jacobs, H. H. (1993). Mathematics integration: A common-sense approach to curriculum development. Arithmetic Teacher, 40(6), 301-302.

Jacobs, H.H. (Ed.). (1989), Interdisciplinary Curriculum: Design and Implementation. Alexandria, VA: Association for Supervision and Curriculum Development.

Jensen, E. (1998). Teaching with the brain in mind. Alexandria, VA: Association for Supervision and Curriculum Development.

Kliebard, H.M. (1992). Forging the American Curriculum.New York. Routledge.

Lake, K. (2011). Integrated Curriculum. School Improvement Research Series. pp. 49-76.

Loepp, F. L. (2007), Models of Curriculum Integration, Journal of Technology Studies, 22 (5)9-30.

Loepp, I. P. (2007). Primary Programs Framework - Curriculum Integration: Making Connections. Alberta: Alberta Education.

Mansfiled, B. (1989). "Students'Perception of an Integrated Unit: A Case Study.” Social Studies. 80 (4) 135-140.

Mohammed, M.O. (n.d) "Integrating at Turath al-Islamic to Modern University Curriculum: Issues and the Need for Benchmark". Islamic Economics Education in Southeast Asian Universities, pp. 75-91.

Murdoch, K., Hamston, J. (1999). Knowing me, knowing you: Exploring identity and difference through an integrated curriculum. Burwood, VIC: Dellasta Publishing.

Murdoch, K., Hornsby, D. (1997). Planning curriculum connections: Whole-school planning for integrated curriculum. South Yarra, VIC: Eleanor Curtain Publishing.

Naqi, S.A. (1987). "Implementation of the Recommendation of the Four World Conferences on Muslim Education in Bangladesh: Problems and their Solutions" Muslim Education Quarterly, 4 (4) 47-49.

Paterson, J. (2003). Curriculum integration in a standards-based world. Middleground: The Magazine of Middle Education, 7(1), 10-12. 
Pring, R. (1973). Curriculum integration. In R.S. Peters (Ed.), The philosophy of education. London: Oxford University Press.

Pring, R. (2006). Curriculum integration. Journal of Philosophy of Education, 5(2), 170-200.

Rosnani, H. (1996). "Islamization and the Role of the Department of Education,International Islamic University”. Paper presented at the Seminar on the Islamization of Knowledge, International Islamic University Malaysia, 22 November, 1996.

Rosnani, H. (1997). The Reconstruction of an Islamic-Based Teacher Education Programme, in Ashraf, A (ed) Muslim Education Quarterly,vol. 14, No. 2,Stoughton: King Abdul-Aziz University.

Rosnani, H. \& Imran, R. (2000). Islamization of Knowledge: A Comparative Analysis of the Conception of Al-Attas and al-Faruqi. Intellectual Discourse, 8 (1): 19-44.

Rosnani, H. (2004). Educational Dualism in Malaysia: Implications forTheory and Practice. Kuala Lumpur: The Other Press

Rosnani, H. (2005). "Rethinking Islamic Education in Facing the Challenges of the Twenty-first Century”.American Journal of Islamic and Social Sciences, 22 (4) 133-147.

Rosnani, H (2007). "Intellectualism in Higher Islamic Traditional Studies: Implications for the Curriculum”. American Journal Of Islamic and Social Sciences.24(3).

Rosnani H. (Ed.).(2010).The Educational Thought of Muslim Scholars in theMalay Archipelago and Islamic Educational Reform.Kuala Lumpur: The Other Press

Rosnani, H. (2011) Internationalisation of Contemporary Islamic Higher Education and Ummatic Development: A Case Study of the International Islamic University Malaysia (IIUM). Paper presented at the International Seminar on Reforms in Islamic Higher Education in Meeting Contemporary Challenges, Nagoya University 30th- 31stJuly 2011.

Rosnani, H \& Ssekamanya, S. (2013), Islamization of Human Knowledge in Theory and Practice: Achievement, Challenges and Prospects in the IIUM Context, IIUM Journal of Educational Studies, 1 (1)1-12.

Rosnani, H. (2014). Higher Education Curriculum Development for Islamization of Knowledge. Islamic Economics Education in Southeast Asian Universities. Pp. 21-73.

Ross, A.(2000). Curriculum construction and critique. London: Falmer Press.

Rufai, S.A. (2012), Proposing an Islamic-based alternative to dominant western and dominant Islamic models of teacher education”. Asean 
Journal of Teaching and Learning in Higher Education. 4 (1) 4460.

Ssekamanya, S. A., M Sahari, N., Nik A. Hisham, M.S., Ismail, N.A.H.

\& Abdullah, A. S. (2007) "Islamization of contemporary knowledge: analyzing the experiences of selected scholars at the IIUM." Unpublished research report.

Ssekamanya, S. A., Suhailah H. \& Nik Ahmad H. I. (2011)."The experience of Islamization of Knowledge at the International Islamic University Malaysia: successes and challenges." In New Intellectual Horizons in Education (ed. Yedullah Kazmi). Gombak: IIUM Press, pp. 91-110.

Ssekamanya, S. A. \& Rosanin, H. (2012) Islamization of contemporary knowledge and reform of education curriculum. In intellectual, Spiritual, Leadership and Human Knowledge Islamization Colloquium (ISLAHI-1), $30^{\text {th }}$ November $-2^{\text {nd }}$ December, 2012, ISTAC, Kuala Lumpur (unpublished

Siddiqi, M. N. Islamization of Knowledge. Reflections on Priorities. American Journal of Islamic Social Sciences (28) 3: 15-33.

Tom, A.R.(1997).Redesigning Teacher Education. New York: State University of New York Press.

Virtue, D. C., Wilson, J. L., Ingram, N. (2009). L.E.S.S can be more! Middle School Journal, 40(3), 4-11.

Wan Mohd Nor (2013). Islamization of Contemporary Knowledge and the Role of the University in the Context of De-Westernization and De-Colonization. A Professorial Lecture. Centre for Advanced Study on Islam, Science and Civilization (CASIS). University Technology Malaysia, June, 2013. 